\title{
THE SURGICAL MANAGEMENT OF GARDNER SYNDROME MANIFESTATION IN THE MAXILLOFACIAL REGION: A CASE REPORT
}

Slobodan Loncarevic ${ }^{1,2}$, Denis Brajkovic ${ }^{1}$, Milica Popovic ${ }^{1}$, Milka Gardasevic ${ }^{2}$, Miona Sekulic ${ }^{1}$ and Suzana Matejic ${ }^{3}$ ${ }^{1}$ Department of dentistry, University of Kragujevac, Serbia, Faculty of medical sciences ${ }^{2}$ Clinic for Maxillofacial surgery, Military Medical Academy, Belgrade, Serbia

${ }^{3}$ Department of forensic medicine, University of Pristina, Serbia, Faculty of medicine situated in Kosovska Mitrovica, Kosovo, Srbija HIRURŠKA INTERVENCIJA GARDNEROVOG SINDROMA MANIFESTOVANOG U MAKSILOFACIJALNOJ REGIJI: PRIKAZ SLUČAJA

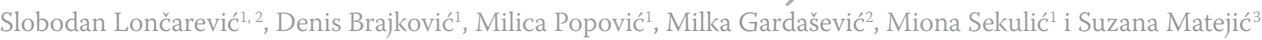

${ }^{1}$ Katedra za stomatologiju, Fakultet medicinskih nauka, Univerzitet u Kragujvcu, Kragujevac, Srbija ${ }^{2}$ Klinika za maksilofacijalnu hirurgiju, Vojno-medicinska akademija, Beograd, Republika Srbija

${ }^{3}$ Katedra za forenzičku medicinu, Medicinski fakultet u Prištini sa sedištem u Kosovskoj Mitrovici, Univerzitet u Prištini, Kosovo, Srbija

\begin{abstract}
APSTRAKT
Gardner syndrome is a rare autosomal-dominant genetic disorder, considered a variant of familial adenomatous polyposis. It is characterized by intestinal polyposis and various bone and soft-tissue tumors, including osteomas, epidermal and dermal cysts, lipomas and fibromas. Intestinal polyps have high potential to become malignant, and the screening of intestinal lesions is mandatory. Maxillofacial manifestations, such as jaw osteomas, odontomas, dental abnormalities and soft tissue tumors frequently precede the intestinal manifestations. Thus, maxillofacial surgeons and dental practitioners may have important role in early detection of Gardner syndrome. In this case report we present a 22 year old male patient who was reffered to maxillofacial surgeon due to osteoma of the mandible. After obtaining clinical and radiological examinations, as well as data from family history, Gardner syndrome was suspected, which was later confirmed after gastroenterological examination.
\end{abstract}

Keywords: gardner syndrome, extraintestinal manifestation, mandible osteoma, treatment

\section{INTRODUCTION}

Gardner syndrome (GS) is a rare autosomal-dominant genetic disorder characterized by multiple colorectal polyps and various types of tumors of the skin, bones and glands (1-4). People affected by GS have a high risk of developing colorectal cancer at an early age as well as other familial adenomatous polyps related cancers: small bowel, stomach, pancreas, thyroid, central nervous system, liver, bile ducts, and adrenal gland. Extraintestinal symptoms of GS include dental abnormalities, odontogenic tumors, osteomas, various skin abnormalities such as epidermoid cysts, fibromas, lipomas and desmoid tumors (4).

\section{SAŽETAK}

Gardnerov sindrom je redak autozomno dominantni genetski poremećaj, varijanta familijarne adenomatozne polipoze. Karakteriše ga polipoza creva i različiti tumori kostiju $i$ mekih tkiva, uključujući osteome, epidermalne i dermalne ciste, lipome i fibromatoze. Crevni polipi imaju visoki maligni potencijal, pa je redovna kontrola ovih lezija od strane gastroenterologa obavezna. Manifestacije u maksilofacijalnoj regiji, kao što su osteomi vilica, odontomi, zubne abnormalnosti i tumori mekog tkiva često prethode crevnim manifestacijama. Dakle, maksilofacijalni hirurzi i stomatolozi mogu imati važnu ulogu u ranom otkrivanju Gardnerovog sindroma. U ovom slučaju prikazujemo 22-godišnjeg muškog pacijenta koji je upućen na pregled maksilofacijalnog hirurga zbog osteoma donje vilice. Na osnovu kliničkog i radiološkog pregleda, kao i na osnovu anamnestičkih podaataka, dijagnostikovan je Gardnerov sindrom, što je potvđeno nakon pregleda gastroenterologa

Ključne reči: gardnerov sindrom, ekstraintestinalna manifestacija, mandibularni osteom, lečenje

The diagnosis of GS is in most cases based on clinical findings. The significance of GS to the oral and maxillofacial surgeons and dental practitioners is that the jaw lesions and dental abnormalities may be apparent before those in the bowel and could be of diagnostic importance $(3,4)$. Early detection of multiple jaw osteomas, odontogenic tumors, supernumerary teeth and multiple cutaneos cysts may lead to appropriate early detection of colon polyps. Since the syndrome is genetically inherited, molecular genetic testing is available and the diagnosis has implications for family members (5). 


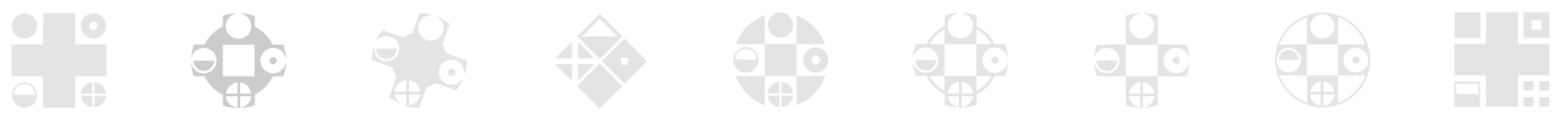

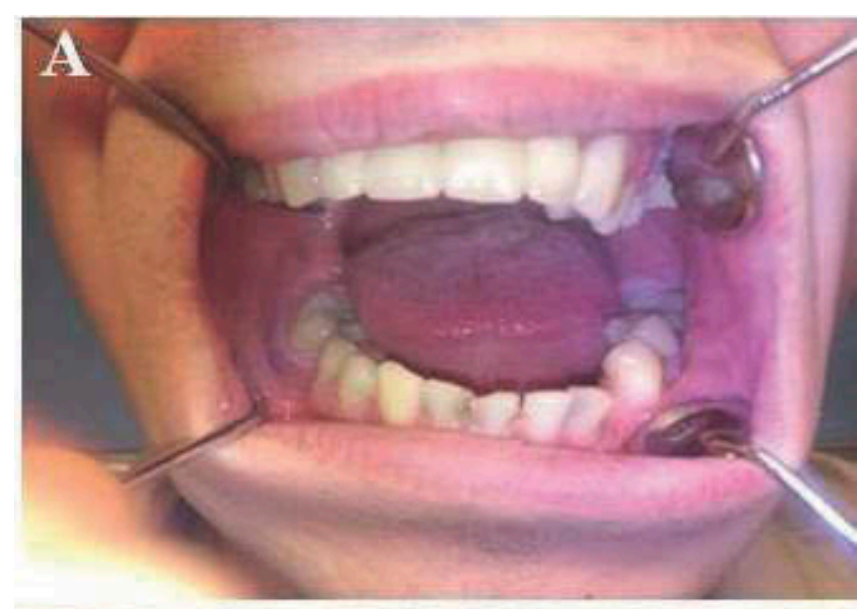
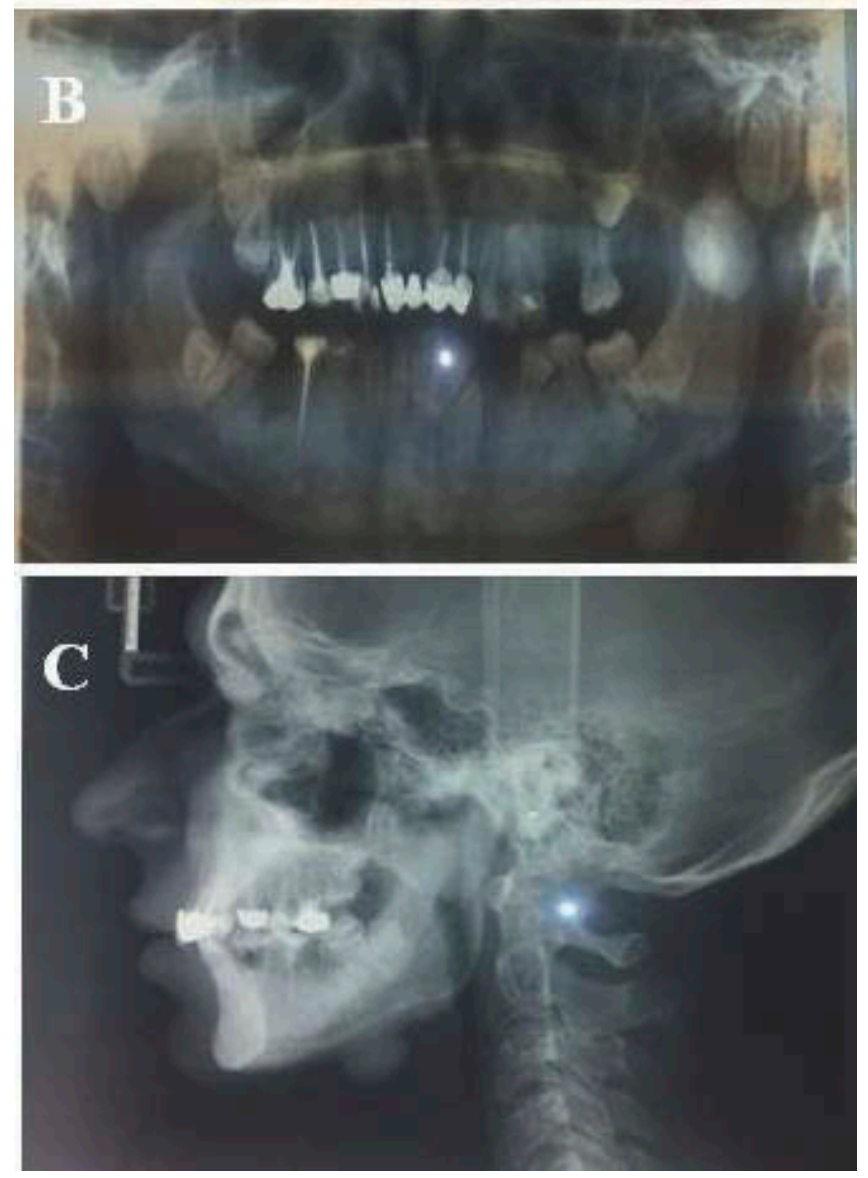

Figure 1. A. An intraoral appearance of patient; B. Panoramic radiograph showing multiple osteomas, impacted teeth, odontomas and diffuse sclerosis throughout the mandibular body; C. Profile view of the skull

Although there is no cure for GS, management options are available to reduce the risk of cancer. Thus colectomy is advised when more than 20 polyps are detected (6). Dental abnormalities may be treated, osteomas and epidermoid/ dermoid tumors may be removed when causing cosmetic or functional disabilities $(1,2)$.

The aim of this case report is to present patient with GS and to discuss management of maxillofacial manifestations and need for screening intestinal lesions.

\section{REPORT OF A CASE}

A 22-year-old male was referred to the Department of Maxillofacial Surgery at Military Academy, Belgrade, Serbia, for the management of mandible osteomas and odontomas as well as dermoid cysts on the neck. In the patient's family history we found out that the patient mother died due to the colon carcinoma and that his sister has similar symptoms.

A panoramic radiograph showed the presence of multiple round radiopaque lesions in the mandible (corpus, ramus and condyle on the left side), impacted teeth and multiple odontomas in both maxilla and the mandible. There was a diffuse bone sclerosis throughout the mandibular body (Fig 1).

The patient main complaint was of cosmetic nature and the visually irregularity of the face. An initial clinical examination showed a hard palpable nodular formation along the left mandibular angle and in the temporomandibular joint region, each measuring approximately 1,5-2 $\mathrm{cm}$ in diameter. On palpation, the lesions were adherent to the bone, hard, well limited, and nonadherent to the skin. There were no disfunction of the temporomandibular joints. The mouth opening was normal. Intraoral examination revealed partial edentulous maxilla and mandible, rotated and inclinated teeth as well as multiple caries lesions. Examination of the neck revealed an dermoid cyst in the left supraclavicular region, measuring approximately $2 \mathrm{~cm}$ in diameter, well limited on palpation, nonadherent to deeper tissues and movable.

The excision of the osteomas of the left mandible condyle was performed via intraoral approach. Each osteoma measured approximately $1,5 \mathrm{~cm}$. Histopathologic examination revealed a dense, acelular compact lamellar bone with minimal marrow spaces and rare irregular Haversian canals. The postoperative course was uneventful.

The patient was instructed that he and his family members need an examination for possible intestinal lesions and genetical testing. Because the suspicion the patient had GS, the gastroenterologist indicated colonoscopy which revealed multiple polyps in the colon and colectomy was indicated.

\section{DISCUSSION}

GS is considered a variant of familial adenomatous polyposis (FAP), in which various extracolonic manifestations develop. GS is caused by mutations in a portion of the APC gene (codons 1403 and 1578) that differs from classic FAP (codons 169-1600) (7). In all untreated patients, cancer of the large intestine develops before the age of 40 (8). This has implication for all family members if the diagnosis is positive. Although there is no cure for GS, people affected must undergo screening for the polyps and associated intestinal tumors to permit early diagnosis and treatment. Standard screening regimens include: 
- Sigmoidoscopy or colonoscopy every one to two years, beginning at age ten to 12 years. Once polyps are detected, colonoscopy is recommended annually until colectomy;

- Eesophagogastroduodenoscopy beginning by age 25 and repeated every one to three years;

- Thyroid evaluation beginning in the late teenage years;

- Screening for desmoid tumors and hepatoblastoma (8-11).

Genetic testing is the most efficient mode of identifying gene mutations in family members and should be assessed before the initiation of regular endoscopic screening (12). Screening colonoscopy should begin at age 10-12 years for patients with proven APC mutations (13). A colectomy is usually recommended when multiple advanced polyps are identified.

The prognosis for people with GS depends on the presence of malignant alteration of colonic polyps and the age of diagnosis (14). By the fourth decade of life more than $95 \%$ of affected people have polyps (10). The polyps rapidly increase in number and without colectomy the colon cancer is inevitable (8). Thus, early diagnosis and management are mandatory. Osteomas in the facial bones and cranium are found in about $25 \%$ of patients affected by GS and frequently precede the diagnosis of colon polyps, which is important for early detection $(15,16)$. The most common localizations of osteomas are cranial vault and mandible $(4,17)$. Osteomas may be removed for cosmetic reasons, usually do not cause medical problems and do not become malignant.

The oral and maxillofacial manifestations of GS can show up before intestinal lesion polyposis which potentiate the role of maxillofacial surgeons in early diagnosis of GS (4). Various orofacial manifestations may be treated if there are cosmetic of functional issues. Dental abnormalities such as impacted teeth, malpositioned teeth, orthodontic anomalies may be treated surgically and orthodonticaly. Surgical treatment of dental abnormalities usually consists of surgical removal of supernumerary and impacted teeth and extirpation of odontogenic tumors. Surgeons should have in mind that there may be increased difficulty of teeth extraction in GS patients because of the dense nature of the alveolar bone and hypercementosis (2). The skin abnormalities associated with Gardner syndrome are mainly of cosmetic concern and do not become malignant (1).

To conclude, maxillofacial surgeons and dental practitioners may have important role in early detection of Gardner syndrome since osteomatous and various dental lesions frequently precede intestinal manifestations of this rare syndrome. Furthermore, these patients as well as their family members should be instructed for genetical testing and screening for intestinal lesions due to the fact that all affected patients develop intestinal polyps which become malignant in high percentage.

\section{REFERENCES}

1. Ben Lagha N, Galeazzi JM, Chapireau D, et al: Surgical management of osteoma associated with a familial Gardner's syndrome. J Oral Maxillofac Surg 2007;65:1234
2. Ramaglia L, Morgese F, Filippella M, et al: Oral and maxillofacial manifestations of Gardner's syndrome associated with growth hormone deficiency: Case report and literature review. Oral Med Oral Pathol Oral Radiol Endod 2007;103:e30

3. Lew D, DeWitt A, Hicks RJ, et al: Osteomas of the condyle associated with Gardner's syndrome causing limited mandibular movement. J Oral Maxillofac Surg 1999;57:1004

4. Boffano P, Bosco GF, Gerbino G. The surgical management of oral and maxillofacial manifestations of Gardner Syndrome. J Oral Maxillofac Surg 2010;68:2549-54

5. Wijn MA, Keller JJ, Giardiello FM, et al: Oral and maxillofacial manifestations of familial adenomatous polyposis. Oral Dis 2007;13: 360

6. Fotiadis C, Tsekouras DK, Antonakis P, et al: Gardner's syndrome: A case report and review of the literature. World J Gastroenterol 2005;11:5408

7. Vogelstein B, Kinzler KW. Colorectal tumors. The Genetic Basis of Human Cancer. New York: McGraw-Hill; 1998;565-587.

8. D Smud, G Augustin, T Kekez, E Kinda, M Majerovic, Z Jelincic. Gardner's syndrome: Genetic testing and colonoscopy are indicated in adolescents and young adults with cranial osteomas: A case report. World J Gastroenterol 2007; 13(28): 3900-3903

9. Galiatsatos P, Foulkes WD. Familial adenomatous polyposis. Am J Gastroenterol 2006;101:385-398. 10. Galle TS, Juel K, Bülow S. Causes of death in familial adenomatous polyposis. Scand J Gastroenterol 1999;34:808-812.

11. Burke CA, Beck GJ, Church JM, van Stolk RU. The natural history of untreated duodenal and ampullary adenomas in patients with familial adenomatous polyposis followed in an endoscopic surveillance program. Gastrointest Endosc 1999;49:358-364.

12. Mak T, Speake D, Lalloo F, Hill J, Evans DG. Familial colorectal cancer referral to regional genetics department--a single centre experience. Fam Cancer 2007;6:81-87.

13. Cruz-Correa M, Giardiello FM. Diagnosis and management of hereditary colon cancer. Gastroenterol Clin North Am 2002;31:537-549

14. Lipkin, M., Blattner, W.A., Gardner, E.J., Winawer, S., Fraumeni, J.F. Classification and Risk Assessment of Individuals with Familial Polyposis, Gardner's Syndrome, and Familial Non-Polyposis Colon Cancer from [3H] Thymidine Labeling Patterns in Colonic Epithelial Cells. Cancer Research 1984; 44 (9):4201

15. Jones EL, Cornell WP. Gardner's syndrome; review of the literature and report on a family. Arch Surg 1966;92:287-300.

16. Bisgaard ML, Bülow S. Familial adenomatous polyposis (FAP): genotype correlation to FAP phenotype with osteomas and sebaceous cysts. Am J Med Genet 2006;140:200-204.

17. Eppley BL, Kim W, Sadove AM. Large osteomas of the cranial vault. J Craniofac Surg 2003;14:97-100. 